\title{
Penerapan Metode AHP-Topsis untuk Mengukur Tingkat Kesejahteraan Masyarakat Pesisir
}

\author{
Moh. Ramdhan Arif Kaluku ${ }^{\mathrm{a}, 1}$ dan Nikmasari Pakayaa,2,* \\ ${ }^{a}$ Teknik Informatika, Universitas Negeri Gorontalo, Jln. Jenderal Sudirman No.6, Gorontalo, Indonesia \\ ${ }^{1}$ aliaskaluku@ung.ac.id; ${ }^{2}$ nikmasaripakaya@ung.ac.id \\ *corresponding author
}

\section{INFORMASI ARTIKEL

$\begin{array}{ll}\text { Dikirim } & : 13 \text { Oktober } 2020 \\ \text { Diulas } & : 17 \text { Desember } 2020 \\ \text { Direvisi } & : 18 \text { Desember } 2020 \\ \text { Diterbitkan } & : 28 \text { Desember } 2020\end{array}$

Kata Kunci:

Kesejahteraan

Pesisir

AHP

TOPSIS

\section{ABSTRAK}

Tujuan dari penelitian ini yaitu memperoleh terobosan terbaru dalam ilmu pengetahuann terutama pada masalah indikator pengembangan kawasan pesisir dan kesejahteraan masyarakat nelayan yang kemudian dapat diimplementasikan dalam aplikasi sistem informasi dengan menggunakan metode AHP-TOPSIS. Dengan menerapkan metode AHP untuk menentukan bobot global dari setiap kriteria, kemudian metode TOPSIS untuk melakukan penilaian pada kondisi kesejahteraan Masyarakat pesisir, penelitian ini bertujuan untuk meninjau faktor-faktor yang dapat mempengaruhi kesejahteraan masyarakat pesisir dengan mengukur tingkat kesejahteraan masyarakat pesisir, dan menerapkan rancangan model ke dalam aplikasi sistem informasi pengukuran kesejahteraan masyarakat pesisir. Prediksi dari tingkat kesejahteraan dapat dilihat dari hasil penelitian yang diperoleh dari perhitungan yang dilakukan. Penilaian pada tingkat kesejahteraan masyarakat menunjukan nilai akhir terbesar dengan 0,8095 , sedangkan nilai terendah dengan nilai 0,1113 .

\begin{abstract}
The purpose of this research is to obtain the latest breakthroughs in science, especially in the problem of indicators of coastal area development and the welfare of fishing communities which can then be implemented in an information system application using the AHP-TOPSIS method. By applying the AHP method to determine the global weight of each criterion, then the TOPSIS method for assessing the welfare conditions of coastal communities, this study aims to review the factors that can affect the welfare of coastal communities by measuring the level of welfare of coastal communities, and applying a model design to in the application of information systems for measuring the welfare of coastal communities. The prediction of the level of welfare can be seen from the research results obtained from the calculations carried out. The assessment of the level of community welfare shows the final value is the largest with 0.8095 , while the lowest value is 0.1113 .
\end{abstract}

This is an open access article under the $\mathrm{CC}-\mathrm{BY}-\mathrm{SA}$ license.

\section{Pendahuluan}

Kemiskinan merupakan menjadi suatu yang sulit untuk di atasi dalam era sekarang ini. Sehingga alasan untuk melakukan evaluasi terhadap kinerja dari pemerintah dalam menangani kemiskinan dirasa perlu dilakukan, dan lebih dari itu, ketidakmampuan dalam menurunkan angka kemiskinan dapat pula menjatuhkan kredibilitas pemerintah [1]. Selama ini untuk menilai tingkat kemiskinan selalu dikaitkan pada pendapatan atau berdasarkan faktor ekonomi warga, ini dikarenakan faktor ekonomi ini dapat dengan mudah untuk diukur, diamati dan diperbandingkan[2]. Namun pertimbangan terhadap faktor lain dalam menilai tingkat kemiskinan dapat dilihat bukan hanya dari faktor ekonomi, tetapi juga dapat dilihat dari faktor budaya, budi pekerti, pendidikan, sosial, lingkungan, sosial politik dan kesehatan [3].

Masyarakat pesisir secara umum masih berhadapan dengan kondisi kemiskinan. Hal itu pula yang menjadi latar belakang diselenggarakannya pembangunan masyarakat pesisir, sehingga pada seluruh desa pesisir lokasi kegiatan masyarakatnya sudah pasti berhadapan dengan kemiskinan [4]. Kabupaten Gorontalo Utara merupakan wilayah yang saat ini menyandang predikat garis pantai terpanjang di Provinsi Gorontalo. Dari 
bentang pantai tersebut, terdapat 78 desa di pesisir yang kebanyakan mata pencaharian dari penduduknya adalah nelayan. Menurut Bupati Gorontalo Utara, untuk bisa bersaing dengan desa non pesisir yang memiliki keberagaman profesi pihaknya harus melakukan berbagai inovasi serta perlu dilaksanakan pembangunan berkelanjutan untuk bisa mengentaskan keterbelakangan yang ada di desa pesisir, termasuk bekerja sama dengan sejumlah perguruan tinggi untuk melaksanakan pembangunan di pesisir [5].

Upaya pembangunan kawasan pesisir khususnya dalam peningkatan kesejateraan masyarakat nelayan di Kabupaten Gorontalo Utara tentu membutuhkan perencanaan yang baik agar pembangunan yang dilakukan dapat terarah dengan baik dalam mengentaskan kemiskinan pada masyarakat di daerah pesisir yang berprofesi sebagai nelayan [3]. Selama ini, penentuan tingkat kesejahteraan dari masyarakat pesisir hanya berdasarkan pendapatan yang diperoleh oleh setiap keluarga. Sehingga penilaian yang dilakukan untuk menentukan tingkat kesejahteraan dari setiap masyarakat selalu monoton pada pendapatan. Padahal, banyak aspek yang bisa menjadi faktor penentuan kesejahteraan masyarakat, diantaranya adalah aspek sosial budaya, dimana interaksi sosial dan budaya setiap masyarakat bisa menjadi faktor yang menentukan juga, sehingga perlu ditambahkan untuk menentukan nilai dari kesejahteraan masyarakat. Oleh sebab itu, untuk mendukung upaya pemerintah tersebut perlu dibuatkan sebuah model pengukuran tingkat kesejahteraan masyarakat pesisir berdasarkan faktor-faktor yang paling mempengaruhi dengan menggunakan metode dalam Pengambilan Keputusan yaitu AHP-TOPSIS. Dengan adanya model pengukuran kesejahteraan ini, diharapkan dapat membentu pemerintah dalam menentukan tingkat kesejahteraan masyarakat pesisir yang dilihat dari semua aspek yang memperngaruhi tingkat kesejahteraan itu.

AHP merupakan metode yang memiliki analisis bertingkat di dalam sistem pengambilan keputusan. Variabel yang di analisis diberikan nilai prioritas, selanjutnya kriteria dan alternatif akan dinilai dengan melakukan perbandingan berpasangan [6]. TOPSIS merupakan metode yang tidak hanya dilihat dari jarak terpendek pada solusi ideal positif, tetapi juga dilihat dari jarak yang paling jauh pada solusi ideal negatif [7]. Metode AHP-TOPSIS adalah kombinasi dari penerapan metode AHP untuk mencari bobot global dari setiap kriteria sedangkan TOPSIS menggunakan bobot yang diperoleh dari AHP untuk melakukan perangkingan [8][9].

\section{Metode}

\section{A. Analytic Hierarchy Process (AHP)}

Model pengambilan keputusan AHP adalah sebuah model pengambilan keputusan yang dikembangkan oleh Thomas L. Saaty untuk menyelesaikan permasalahan kompleks yang bersifat hierarki [6]. [10] Suatu bentuk hirarki pada model AHP ditetapkan berdasarkan level dari setiap indokator dan alternatif, pada level pertama hierarki terdapat tujuan atau goal dari permasalahan, setelah itu level kedua terdapat kriteria dan sub kriteria, kemudian pada level terakhir terdapat alternatif. Penggunaan AHP yang mengandung unsur hirarki, dilakukan dengan cara mengabungkan masalah ke dalam kelompok-kelompok lebih terstruktur serta sistematis.

Adapun langkah-langkah penyelesaian metode AHP yaitu [6]:

1) Menentukan permasalahan dan solusi

Pada tahapan ini, identifikasi terhadap permasalahan yang ada serta solusi yang ingin dicapi dalam menyelesaiakan masalah itu harus terlebih dulu ditentukan agar memperoleh gambaran umum dari penyelesaian masalah.

2) Menentukan prioritas elemen

a) Membuat perbandingan berpasangan dengan mengelompokkan setiap kriteria dengan kelompok kriteria yang sama.

b) Langkah selanjutnya adalah membuat matriks perbandingan berpasangan untuk membandingkan setiap kriteria yang ada.

c) Matriks perbandingan berpasanagan diberi nilai 1-9 sesuai yang telah ditetapkan.

3) Menghitung bobot elemen

Bobot dari masing-masing elemen pada ditentukan berdasarkan analisis pada setiap perhitungan yang dilakukan pada metode AHP untuk menilai baik tidaknya konsistensi dan nilai yang telah ditetapkan sebelumnya.

4) Menghitung Indeks Konsistensi:

Penentuan indeks konsistensi bertujuan untuk memperoleh nilai konsistensi awal yang merupakan perhitungan nilai pengujian.

\section{5) Hitung Rasio Konsistensi}

$$
\mathrm{CI}:(\lambda \text { maks-n) / (n-1) }
$$

Rasio konsistensi merupakan nilai akhir dari perhitungan, dimana penentuan nilai dari setiap vector prioritas dapat diterima atau tidak.

$\mathrm{CR}: \mathrm{CI} / \mathrm{IR}$ 


\section{Keterangan CR : Consistency Ratio \\ CI : Consistency Index \\ IR : Indeks Random Consistency}

Jika nilai CR yang diperoleh dari matriks perbandingan berpasangan lebih kecil dari 0,1 maka konsistensi dapat diterima, jika lebih tinggi dari 0,1 maka perlu dilakuakn perhitungan kembali.

\section{B. TOPSIS (Technique for Order Preference by Similarity to an Ideal Solution)}

Pemilihan indikator yang sesuai merupakan hal penting dalam melakukan evaluasi dengan metode TOPSIS, sehingganya perlu adanya pemilihan indikator yang tepat [11]. Adapun langkah-langkah penyelesaian pada metode TOPSIS yaitu [12][13].

1) Menentukan ranking kinerja setiap alternatif Ai terhadap setiap kriteria Cj yang ternormalisasi.

$$
\mathrm{rij}=\frac{x i j}{\sqrt{\sum_{i=1}^{m} \mathrm{x}_{\mathrm{ij}}^{2}}}
$$

Dimane., $\quad \sqrt{i=1}_{i=1} x_{\mathrm{ij}}^{2}$ lai dari rating kinerja, serta $\mathrm{x}_{\mathrm{ij}}$ merupakan nilai dari setiap atribut pada setiap kriteria dengan $\mathrm{i}=1,2, \ldots . . . \mathrm{m}$; dan $\mathrm{j}=1,2, \ldots \ldots, . . \mathrm{n}$;

2) Hitung nilai dari Matriks keputusan ternomalisasi terbobot $Y_{i j}=W_{i} r_{i j}$

Dimana untuk mendapatkan matriks ternormalisasi terbobot $=\mathrm{Y}_{\mathrm{ij}}$, dilakukan dengan cara bobot preferensi $\mathrm{W}$ dikalikan dengan matriks keputusan ternormalisasi

3) Hitung matriks solusi ideal positif serta matriks solusi ideal negatif

$A^{+}=\left(y_{1}^{+}, y_{2}^{+}, \ldots, y_{n}^{+}\right)$;

$A^{-}=\left(y_{1}^{-}, y_{2}^{-}, \ldots, y_{n}^{-}\right)$;

Dengan :

$y_{j}^{+}$merupakan nilai Max $y_{i j}$ jika $j$ merupakan atribut keuntungan

Max $y_{i j}$ jika $j$ merupakan atribut biaya

$y_{j}^{-}$merupakan Min $y_{i j}$ jika $j$ merupakan atribut keuntungan

Min $y_{i j}$ jika $j$ merupakan atribut biaya

4) Menghitung jarak setiap alternatif dengan matriks solusi ideal positif serta matrik solusi ideal negatif.

$$
\begin{gathered}
D_{i}^{+}=\sqrt{\sum_{j=1}^{m}\left(y_{i}^{+}-y_{i j}\right)^{2}} ; \mathrm{i}=1,2, \ldots, \mathrm{m} \\
\quad \text { Alternatif untuk solusi ideal negatif. } \\
D_{i}^{-}=\sqrt{\sum_{j=1}^{m}\left(y_{i j}-y_{i}^{-}\right)^{2}} ; \mathrm{i}=1,2, \ldots, \mathrm{m}
\end{gathered}
$$

Dengan $\mathrm{D}_{\mathrm{i}}^{+}$merupakan jarak solusi ideal positif untuk alternatif ke- $i$ sedangkan $\mathrm{D}_{\mathrm{i}}^{-}$merupakan jarak solusi ideal negatif.

5) Hitung nilai preferensi pada semua alternatif $\left(V_{i}\right)$.

$$
V_{i}=\frac{D_{i}^{-}}{D_{i}^{-}+D_{i}^{+}} \quad \mathrm{i}=1,2, \ldots, \mathrm{m}
$$

Nilai preferensi merupakan nilai yang diperoleh dari perbandingan antara solusi ideal positif dan solusi ideal negatif melalui perhitungan yang telah dilakukan sebelumnya. Nilai preferensi yang dihasilkan, kemudian di urutkan dari yang teringgi sampai yang terenda. Adapun alternatif yang memiliki nilai preferensi yang paling besar menunjukan bahwa alternatif tersebut terpilih [14].

\section{Hasil dan Pembahasan}

Penelitian ini dilakukan dengan menggabungkan metode AHP dan metode TOPSIS. Kedua metode ini merupakan metode dalam model Pendukung Keputusan yang mengkombinasikan metode AHP pada pembobotan dan TOPSIS pada perangkingan. Metode ini dipilih karena metode AHP dapat menyelesaikan masalah yang bersumber dari unsur hierarki yang hasil dari perhitungannya dapat menganalisis konsistensi. Sedangkan pada metode TOPSIS sendiri, digunakan karena metode ini dapat mengukur nilai yang tepat, karena tidak hanya melihat dari solusi yang terbaik, melaikan juga berdasarkan solusi yang terburuk serta penyelesaian masalah dengan menggunakan metode ini bersifat praktis dan mudah dipahami [8].

Sebelumnya terlebih dahulu akan ditentukan kriteria dan sub kriteria dalam mengukur tingkat kesejahteraan masyarkat pesisir. Tahapan ini menghasilkan kriteria dan sub kriteria untuk menentukan peringkat dari kesejahteraan masyarakat pesisir. Kriteria dan sub kriteria terdiri dari dimensi penilaian terdiri 
dari 4, Adapun kriteria pengukuran kinerja yang digunakan, berdasarkan observasi yang dilakukan terhadap masyarakat dan instansi pemerintah seperti pada Tabel 1.

Tabel 1. Kriteria Kesejahteraan [3]

\begin{tabular}{|c|c|c|}
\hline No & Kriteria & Subkriteria \\
\hline \multirow{3}{*}{1} & \multirow{3}{*}{ pembangunan kawasan pesisir (w) } & program pengembangan kapabilitas (w.1) \\
\hline & & program penningkatan pendapatan (w.2) \\
\hline & & penyediaan infrastruktur (w.3) \\
\hline \multirow{2}{*}{2} & \multirow{2}{*}{ lingkungan hidup masyarakat pesisir (x) } & mutu lingkungan hidup (x.1) \\
\hline & & jasa - jasa lingkungan (x.2) \\
\hline \multirow{2}{*}{3} & \multirow{2}{*}{ perilaku adaptasi ekonomi masyarakat nelayan (y) } & adaptasi fungsional (y.1) \\
\hline & & adaptasi prosesual (y.2) \\
\hline \multirow{7}{*}{4} & \multirow{7}{*}{ kesejahteraan masyarakat nelayan (z) } & pendapatan (z.1) \\
\hline & & tabungan (z.2) \\
\hline & & rekening listrik (z.3) \\
\hline & & kepemilikan perahu dan peralatan nelayan (z.4) \\
\hline & & perumahan (z.5) \\
\hline & & pendidikan (z.6) \\
\hline & & kesehatan (z.7) \\
\hline
\end{tabular}

Penelitian ini menghasilkan sebuah model pengambilan keputusan, menggunakan menggabungkan metode AHP dengan metode TOPSIS. Pada penelitian ini menghasilkan empat kriteria yang diperoleh dari hasil wawancara sebagai dasar acuan dalam menentukan subkriteria kesejahteraan masyarakat. Selanjutnya dari setiap subkriteria yang ada, responden akan dibuatkan pertanyaan. Dari pertanyaan-pertanyaan ini, kemudian dugunakan sebagai dasar dalam penentuan bobot pada pada setiap alternatif. Kriteria yang ada digunakan untuk mengimplementasikan metode AHP untuk menganalisa pengukuran kesejahteraan. Keterkaitan antara setiap kriteria merupakan langkah awal pengukuran yang dilakukan dengan menggunakan metode AHP [15].

Perbandingan berpasangan antar kriteria merupakan hal hal pertama yang dilakukan dengan menggunakan matriks perbandingan berpasangan, selanjutnya dari setiap subkriteria yang ada dilakukan kembali perbandingan berpasangan sehingga memperoleh vector prioritas dari masing-masing sub kriteria, setelah vektor prioritas dari kriteria dan subkriteria diperoleh kemudian keduanya saling dikalikan [16]. Lalu diperoleh bobot global dari hasil perkalian antara kriteria dengan subkriteria tersebut yang disajikan dalam bentuk tabel pada Tabel 2.

Tabel 2. Bobot Global AHP

\begin{tabular}{|c|c|c|c|}
\hline \multicolumn{2}{|c|}{ Kriteria } & \multirow{2}{*}{$\begin{array}{c}\text { Sub kriteria } \\
0,5247\end{array}$} & \multirow{2}{*}{$\begin{array}{l}\text { Bobot } \\
\text { global }\end{array}$} \\
\hline \multirow{3}{*}{ W } & \multirow{3}{*}{0,2746} & & \\
\hline & & 0,3338 & 0,0916 \\
\hline & & 0,1416 & 0,0389 \\
\hline \multirow{2}{*}{$X$} & \multirow{2}{*}{0,1381} & 0,1667 & 0,0230 \\
\hline & & 0,8333 & 0,1151 \\
\hline \multirow{2}{*}{$\mathrm{Y}$} & \multirow{2}{*}{0,5401} & 0,2500 & 0,1350 \\
\hline & & 0,7500 & 0,4051 \\
\hline \multirow{7}{*}{$\mathrm{Z}$} & \multirow{7}{*}{0,0472} & 0,2434 & 0,0115 \\
\hline & & 0,2447 & 0,0116 \\
\hline & & 0,1238 & 0,0058 \\
\hline & & 0,1706 & 0,0081 \\
\hline & & 0,0898 & 0,0042 \\
\hline & & 0,0978 & 0,0046 \\
\hline & & 0,0299 & 0,0014 \\
\hline
\end{tabular}


Nilai bobot global dari setiap subkriteria dapat dilihat pada tabel 2 yang diperoleh dari perkalian antara kriteria dengan subkriteria berdasarkan matriks perbandingan berpasangan yang dibuat sebelumnya. Pada tabel 2 diperoleh subkriteria Y2 mempunyai nilai tertinggi dengan nilai 0,0,4051.

Selanjutnya pemeringkatan dilakukan dengan menggunakan metode TOPSIS. Sebelumnya pada metode AHP telah diperoleh bobot global yang kemudian digunakan pada metode TOPSIS. Pada metode ini, digunakan data hasil kuesioner yang dibagikan yang sebelumnya telah di isi oleh responden. Jawaban dari hasil pertanyaan dari responden kemudian dihitung menggunakan metode TOPSIS. Responden mengisi setiap subkriteria dari kuesioner yang dibagikan menggunakan rating kecocokan untuk menilai setiap alternatif terhadap masing-masing subkriteria yang ada [8][14].

Dengan menggabungkan AHP-TOPSIS, hasil yang diperoleh berbeda satu dengan lainnya. Hal ini dipengaruhi oleh nilai yang diberikan oleh setiap responden yang ada, yang kemudian dapat digunakan menjadi rekomendasi penilaian tingkat kesejahteraan masyarakat yang ada di Kabupaten Gorontalo Utara. Hasil akhir dari pengukuran tingkat kesejahteraan ini menunjukan tingkat kesejahteraan setiap masyarakat yang telah dirangking.

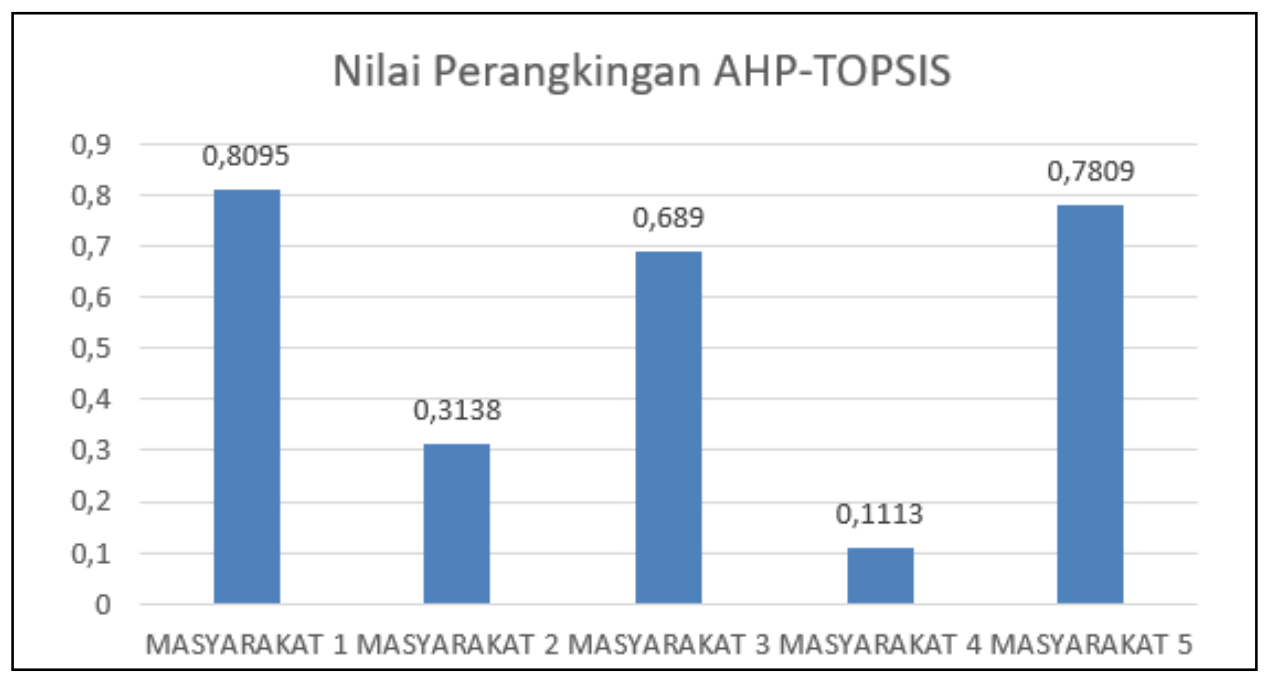

Gambar 1. Hasil Perangkingan AHP-TOPSIS

Hasil grafik pada Gambar 1, terlihat Masyarakat 1 memiliki nilai paling tinggi dengan nilai 0,8095 sedangkan mMasyarakat 4 memiliki nilai paling rendah yaitu 0,1113 . Sehingga terlihat bahwa tingkat kesejahteraan Masyarakat1 lebih baik daripada masyarakat yang lain.

Sebelumnya, responden dari unsur masyarakat dan responden dari unsur pemerintahan sebanyak 30 responden disebar kuesionert untuk menilai tingkat kesejahteraan masyarakat pesisir di kabupaten Gorontalo Utara. Dari hasil yang diperoleh pada perhitungan yang menggunakan metode AHP serta metode TOPSIS, akan digunakan sebagai acuan untuk penilaian tingkat kesejahteraan masyarakat pesisir.

Pengukuran tingkat kesejahteraan masyarakat pesisir dilakuakn dengan menghitungan bobot dari setiap kriteria menggunakan metode AHP. Pada metode AHP ini, dilakukan identifikasi subkriteria apa saja yang saling berhubungan dengan masing-masing kriteria agar mempermudah dalam menilai matriks perbandingan berpasangan. Matriks perbandingan berpasangan antar kriteria dibuat berdasarkan jumlah kriteria yang ada, yang dibandingankan dengan semua kriteria yang ada [17].

Tabel 3. Matriks perbandingan berpasangan antar kriteria

\begin{tabular}{ccccc}
\hline Kriteria & $\mathrm{W}$ & $\mathrm{X}$ & $\mathrm{Y}$ & $\mathrm{Z}$ \\
\hline $\mathrm{W}$ & 1 & 3 & $1 / 3$ & 7 \\
\hline $\mathrm{X}$ & 0,333333333 & 1 & $1 / 5$ & 5 \\
\hline $\mathrm{Y}$ & 3 & 5 & 1 & 7 \\
\hline $\mathrm{Z}$ & 0,142857143 & 0,2 & 0,142857143 & 1 \\
\hline Jumlah & 4,4762 & 9,2000 & 1,6762 & 20,0000 \\
\hline
\end{tabular}

Setelah perbandingan berpasangan dibuat, kemudian dilakukan perhitungan bobot dari masing-masing kriteria yang dinilai, sehingga menghasilkan bobot prioritas dari masing-masing kriteria seperti terlihat pada 
Tabel 3. Pada Tabel 4, matriks perbandingan berpasangan menunjukan kriteria Y memiliki nilai vektor prioritas tertinggi dengan 0,5401, sedangkan kriteria $\mathrm{Z}$ memiliki nilai terendah dengan 0,0472.

Tabel 4. Matriks perhitungan bobot vektor prioritas antar kriteria

\begin{tabular}{cccccc} 
Kriteria & A1 & A2 & A3 & A4 & $\begin{array}{c}\text { Vektor } \\
\text { Prioritas }\end{array}$ \\
\hline A1 & 0,2234 & 0,3261 & 0,1989 & 0,3500 & 0,2746 \\
\hline A2 & 0,0745 & 0,1087 & 0,1193 & 0,2500 & 0,1381 \\
\hline A3 & 0,6702 & 0,5435 & 0,5966 & 0,3500 & 0,5401 \\
\hline A4 & 0,0319 & 0,0217 & 0,0852 & 0,0500 & 0,0472 \\
\hline Jumlah & 1,0000 & 1,0000 & 1,0000 & 1,0000 & 1,0000 \\
\hline
\end{tabular}

Nilai vektor prioritas merupakan nilai yang diperoleh dengan menormasilasai matriks perbandingan berpasangan yang telah di buat sebelumnya, nilai pada masing-masing kolom pada matriks perbandingan berpasangan di peroleh dengan membagi setiap nilai kriteria dengan hasil jumlah nilai masing-masing kolom, sehingga diperolehlah nilai vektor prioritas seperti yang ada pada Tabel 4. Setelah proses normaslisasi selesai, kemudian dilakukan perhitungan rasio konsistensi seperti yang sudah ditetapkan, proses perhitungan ini dimulai dengan mencari nilai dari Eigen Max, seperti nampak pada Tabel 5.

Tabel 5. Perhitungan Nilai Eigen Max antar kriteria

\begin{tabular}{cccc}
\hline Kriteria & Vektor prioritas & Hasil Kali & Hasil Kali/Rata2 \\
\hline A1 & 0,2746 & 1,1995 & 4,3684 \\
\hline A2 & 0,1381 & 0,5738 & 4,1541 \\
\hline A3 & 0,5401 & 2,3850 & 4,4161 \\
\hline A4 & 0,0472 & 0,1912 & 4,0496 \\
\hline Jumlah & 1,0000 & 4,3495 & 16,9882 \\
\hline
\end{tabular}

$$
\begin{aligned}
\mathrm{CI} & =(\text { ( max }-\mathrm{n}) /(\mathrm{n}-1) \\
& =(4,2470-4) /(4-1) \\
& =0,0823 \\
\mathrm{CR} & =\mathrm{CI} / \mathrm{IR} \\
& =0,0823 / 0,9 \\
& =0,0915
\end{aligned}
$$

Pada tahap ini, konsistensi rasio tidak boleh lebih dari 0,1 , apabila melebihi 0,1 maka perbandingan berpasangan harus dilakukan kembali dari awal. Pada tahap ini telah dilakukan perhitungan dan menghasilkan konsistensi rasio 0,0915 atau lebih kecil dai 0,1 sehingga bobot prioritas yang bersumber dari perbandingan berpasangan dapat diterima.Setelah bobot prioritas atau vektor prioritas dari masing-masing kriteria diperoleh, maka tahap selanjutnya adalah mencari vektor prioritas dengan perbandingan berpasangan antara masingmasing sub kriteria pada masing-masing kriteria, dengan menggunakan cara yang sama dengan perhitungan perbandingan berpasangan pada penilaian kriteria sampai dengan menghasilkan nilai konsistensi rasio dapat dilihat pada Tabel 6 .

Tabel 6. Matriks perbandingan berpasangan antar subkriteria pada kriteria Z

\begin{tabular}{rccccccc}
\hline $\mathrm{Z}$ & $\mathrm{Z} 1$ & $\mathrm{Z} 2$ & $\mathrm{Z3}$ & $\mathrm{Z} 4$ & $\mathrm{Z} 5$ & $\mathrm{Z} 6$ & $\mathrm{Z7}$ \\
\hline $\mathrm{Z} 1$ & 1 & 1 & 3 & 1 & 3 & 5 & 5 \\
\hline $\mathrm{Z} 2$ & 1 & 1 & 3 & 3 & 3 & 1 & 5 \\
\hline $\mathrm{Z} 3$ & 0,3333 & 0,3333 & 1,0000 & 1 & 1 & 3 & 5 \\
\hline $\mathrm{Z} 4$ & 1,0000 & 0,3333 & 1,0000 & 1,0000 & 3 & 3 & 5 \\
\hline $\mathrm{Z} 5$ & 0,3333 & 0,3333 & 1,0000 & 0,3333 & 1,0000 & 1 & 5 \\
\hline $\mathrm{Z6}$ & 0,2000 & 1,0000 & 0,3333 & 0,3333 & 1,0000 & 1,0000 & 5 \\
\hline $\mathrm{Z7}$ & 0,2000 & 0,2000 & 0,2000 & 0,2000 & 0,2000 & 0,2000 & 1,0000 \\
\hline Jumlah & 4,0667 & 4,2000 & 9,5333 & 6,8667 & 12,2000 & 14,2000 & 31,0000 \\
\hline
\end{tabular}


Tabel 7. Matriks perhitungan bobot vektor prioritas antar subkriteria pada kriteria Z

\begin{tabular}{ccccccccc}
\hline Kriteria & $\mathrm{Z} 1$ & $\mathrm{Z} 2$ & $\mathrm{Z} 3$ & $\mathrm{Z} 4$ & $\mathrm{Z} 5$ & $\mathrm{Z} 6$ & $\mathrm{Z} 7$ & $\begin{array}{c}\text { Vektor } \\
\text { Prioritas }\end{array}$ \\
\hline $\mathrm{Z} 1$ & 0,2459 & 0,2381 & 0,3147 & 0,1456 & 0,2459 & 0,3521 & 0,1613 & 0,2434 \\
\hline $\mathrm{Z} 2$ & 0,2459 & 0,2381 & 0,3147 & 0,4369 & 0,2459 & 0,0704 & 0,1613 & 0,2447 \\
\hline $\mathrm{Z3}$ & 0,0820 & 0,0794 & 0,1049 & 0,1456 & 0,0820 & 0,2113 & 0,1613 & 0,1238 \\
\hline $\mathrm{Z} 4$ & 0,2459 & 0,0794 & 0,1049 & 0,1456 & 0,2459 & 0,2113 & 0,1613 & 0,1706 \\
\hline $\mathrm{Z} 5$ & 0,0820 & 0,0794 & 0,1049 & 0,0485 & 0,0820 & 0,0704 & 0,1613 & 0,0898 \\
\hline $\mathrm{Z6}$ & 0,0492 & 0,2381 & 0,0350 & 0,0485 & 0,0820 & 0,0704 & 0,1613 & 0,0978 \\
\hline $\mathrm{Z7}$ & 0,0492 & 0,0476 & 0,0210 & 0,0291 & 0,0164 & 0,0141 & 0,0323 & 0,0299 \\
\hline Jumlah & 1,0000 & 1,0000 & 1,0000 & 1,0000 & 1,0000 & 1,0000 & 1,0000 & 1,0000 \\
\hline
\end{tabular}

$\underline{\text { Tabel 8. Perhitungan Nilai Eigen Max antar subkriteria pada kriteria } \mathrm{Z}}$

\begin{tabular}{cccc}
\hline Subkriteria & Vektor prioritas & Hasil Kali & Hasil Kali/Rata2 \\
\hline Z1 & 0,2434 & 1,9380 & 7,9631 \\
\hline Z2 & 0,2447 & 1,8881 & 7,7147 \\
\hline Z3 & 0,1238 & 0,9899 & 7,9983 \\
\hline Z4 & 0,1706 & 1,3318 & 7,8059 \\
\hline Z5 & 0,0898 & 0,6806 & 7,5814 \\
\hline Z7 & 0,0978 & 0,7288 & 7,4539 \\
\hline Jumlah & 0,0299 & 0,2240 & 7,4781 \\
\hline
\end{tabular}

$$
\begin{aligned}
\mathrm{CI} & =(\text { max }-\mathrm{n}) /(\mathrm{n}-1) \\
& =(7,7136-7) /(7-1) \\
& =0,1189
\end{aligned}
$$

$$
\begin{aligned}
\mathrm{CR} & =\mathrm{CI} / \mathrm{IR} \\
& =0,1189 / 1,32 \\
& =0,0901
\end{aligned}
$$

Perbandingan matriks dilakukan pada semua subkriteria yang yang ada pada masing-masing kriteria penilaian. Setelah seluruh vektor prioritas dari masing-masing kriteria dan subkriteria di peroleh, tahap selanjutnya yaitu menghitung nilai bobot global dengan mengkalikan setiap kriteria dengan setiap subkriteria yang sesuai, seperti yang terlihat pada Tabel 2.

Pada langkah AHP ini, bobot global diperoleh dari hasil perkalian vektor prioritas akan digunakan sebagai bobot preferensi pada metode TOPSIS [8]. Dari perhitungan yang telah dilakukan menggunakan metode AHP, maka diperolehlah nilai bobot global dari masing-masing subkriteria berturut-turut adalah 0,$1441 ; 0,0916$; 0,$0389 ; 0,0230 ; 0,1151 ; 0,1350 ; 0,4051 ; 0,0115 ; 0,0116 ; 0,0058 ; 0,0081 ; 0,0042 ; 0,0046 ; 0,0014$.

\begin{tabular}{|c|c|c|c|c|c|c|c|c|c|c|c|c|c|c|}
\hline \multirow[b]{2}{*}{ Alternatif } & \multicolumn{14}{|c|}{ Kriteria } \\
\hline & W1 & W2 & W3 & $\mathrm{X} 1$ & $\mathrm{X} 2$ & Y1 & $\mathrm{Y} 2$ & $\mathrm{Z} 1$ & $\mathrm{Z} 2$ & $\mathrm{Z3}$ & $\mathrm{Z4}$ & $\mathrm{Z} 5$ & Z6 & $\mathrm{Z7}$ \\
\hline Masyarakat 1 & 0,4808 & 0,4449 & 0,4689 & 0,3844 & 0,4808 & 0,4449 & 0,4689 & 0,3844 & 0,4689 & 0,3844 & 0,4808 & 0,4449 & 0,4689 & 0,3844 \\
\hline Masyarakat 2 & 0,4274 & 0,4624 & 0,4211 & 0,4964 & 0,4274 & 0,4624 & 0,4211 & 0,4964 & 0,4211 & 0,4964 & 0,4274 & 0,4624 & 0,4211 & 0,4964 \\
\hline Masyarakat 3 & 0,4323 & 0,4755 & 0,4602 & 0,4526 & 0,4323 & 0,4755 & 0,4602 & 0,4526 & 0,4602 & 0,4526 & 0,4323 & 0,4755 & 0,4602 & 0,4526 \\
\hline Masyarakat 4 & 0,4468 & 0,4100 & 0,4037 & 0,4574 & 0,4468 & 0,4100 & 0,4037 & 0,4574 & 0,4037 & 0,4574 & 0,4468 & 0,4100 & 0,4037 & 0,4574 \\
\hline Masyarakat 5 & 0,4468 & 0,4406 & 0,4775 & 0,4380 & 0,4468 & 0,4406 & 0,4775 & 0,4380 & 0,4775 & 0,4380 & 0,4468 & 0,4406 & 0,4775 & 0,4380 \\
\hline
\end{tabular}

Setelah proses perhitungan menggunakan AHP selesai, selanjutnya perangkingan dilakukan dengan menggunakan TOPSIS. Perhitungan dengan menggunakan metode TOPSIS diawali dengan mengisi tabel keputusan dari setiap kriteria pada tiap-tiap alternatif yang diperoleh dari hasil kuesioner yang telah dibagikan sebelumnya pada responden.

Tabel 9. Tabel Keputusan 
Proses dengan metode TOPSIS kemudian dilanjutkan dengan normalisasi matriks dari tabel keputusan. Dimana, setiap nilai dari masing-masing kolom pada setiap subkriteria dari Tabel 9 akan dikalikan dengan bobot global yang telah diperoleh dari perhitungan pada metode AHP sebelumnya. Hasil dari matriks keputusan terbobot, kemudian ditentukan solusi ideal positif dan solusi ideal negatif dengan memilih nilai tertinggi dan terendah dari matriks ternormalisasi terbobot. Setelah nilai dari solusi ideal positif dan solusi ideal negatif diperoleh, maka setiap elemen pada setiap baris alternatif dikalikan dengan nilai pada solusi ideal postif dan solusi ideal negatif, sehingga diperoleh nilai dari jarak solusi ideal positif dan jarak solusi ideal negatif seperti tampak pada Tabel 10. Kemudian ditentukan nilai preferensi akhir dari masing-masing alternatif berdasarkan jarak solusi ideal positif dan negatif yang ada sehingga meghasilkan nilai akhir yang kemudian akan dilakukan perangkingan seperti pada Tabel 11.

Tabel 10. Nilai Jarak Solusi Ideal Positif dan Jarak Solusi Ideal Negatif

\begin{tabular}{lcccc}
\hline \multirow{2}{*}{ Alternatif } & \multicolumn{3}{c}{ Jarak Solusi Ideal } \\
\cline { 2 - 5 } Masyarakat 1 & D1+ & 0,0068 & D1- & 0,0289 \\
\hline Masyarakat 2 & D2+ & 0,0251 & D2- & 0,0115 \\
\hline Masyarakat 3 & D3+ & 0,0115 & D3- & 0,0254 \\
\hline Masyarakat 4 & D4+ & 0,0325 & D4- & 0,0041 \\
\hline Masyarakat 5 & D5+ & 0,0086 & D5- & 0,0307 \\
\hline
\end{tabular}

Tabel 11. Perangkingan Alternatif

\begin{tabular}{ccc}
\hline & \multicolumn{2}{c}{ Nilai preferensi } \\
\cline { 2 - 3 } Alternatif & \multicolumn{2}{c}{ Tiap alternatif } \\
\hline Masyarakat 1 & V1 & 0,8095 \\
\hline Masyarakat 2 & V2 & 0,3138 \\
\hline Masyarakat 3 & V3 & 0,6890 \\
\hline Masyarakat 4 & V4 & 0,1113 \\
\hline Masyarakat 5 & V5 & 0,7809 \\
\hline
\end{tabular}

Penilaian pada tingkat kesejahteraan masyarakat dengan menerapkan metode AHP-TOPSIS menunjukan nilai akhir berupa rangking dari setiap alternatif, hal ini terlihat dari perangkingan pada alternatif yang memiliki nilai terbesar sampai alternatif yang memiliki nilai terkecil. Nilai Masyarakat 1 merupakan nilai terbesar dengan 0,8095 disusul Masyarakat 5 dengan 0,7809, kemudian Masyarakat 3 dengan nilai 0,6890, selanjutnya Masyarakat 2 dengan 0,3138, dan terakhir alternatif 4 dengan nilai 0,1113.

\section{Kesimpulan}

Penelitian ini dapat digunakan untuk membantu dalam proses pengambilan keputusan dan mencari solusi terhadap alternatif dalam mengukur tingkat kesejahteraan masayarakat pesisir yang ada di Gorontalo. Sehingga bisa diketahui bukan hanya dari pendapatan masyarakat tetapi bersumber dari seluruh aspek sosial dan budaya yang ada di masyarakat, karena pada observasi diperoleh bahwa penilaian kesejahteraan tidak melibatkan aspek sosial budaya dalam mengukur tingkat kesejahteraan. Metode AHP digunakan untuk mencari bobot dari masing-masing subkriteria yang akan digunakan untuk mengukur tingkat kesejahteraan dengan menggunakan nilai inputan yang sama. Hasil dari bobot masing-masing subkriteria yang diperoleh dari metode AHP digunakan kembali untuk mengukur tingkat kesejahteraan dan merangking tingkat kesejahteraan dari masing-masing masayarakat menggunakan metode TOPSIS. Hasil penelitian menunjukkan bahwa metode yang diusulkan dapat digunakan untuk membangun sebuah prediksi tingkat kesejahteraan masayarakat, dari penelitian diperoleh nilai tingkat kesejahteraan tertinggi pada masyarakat menggunakan metode AHP-TOPSIS adalah 0,8095 sedangkan nilai terendah adalah 0,1113 .

\section{Daftar Pustaka}

[1] U. Hairah. "Pengembangan Sistem Manajemen Database dan Pengambilan Keputusan kriteria Penduduk Miskin Kabupaten Kutai Kartanegara Kalimantan Timur’. ILKOM Jurnal Ilmiah, 8(1), pp. 9-16. 2016

[2] H. Lahuddin. "Rancangan Sistem Pendukung Keputusan Penentuan Penerima Bantuan Program Pemerintah”. ILKOM Jurnal Ilmiah, 8(1), pp. 63-68. 2016 
[3] R. Hiola, Rama. "Model Of Fishing Communities Welfare In Coastal Area In Gorontalo Utara District" dalam Proceeding International Seminar on Public Health and Education (ISPHE), 2014, Semarang: Universitas Negeri Semarang

[4] S.P. Ginting. "Pengelolaan Pesisir Terpadu. Pembelajaran Dari Pembangunan Masyarakat Pesisir. Jakarta: Direktorat Jenderal Kelautan, Pesisir dan Pulau-pulau Kecil”. Kementerian Kelautan dan Perikanan. 2016

[5] M. Ambari. "Wisata Pesisir, Potensi Terpendam di Gorontalo Utara", Mongabay, 16 Maret, 2018. [Online]. Available: http://www.mongabay.co.id/2017/09/02/wisata-pesisir-potensi-terpendam-digorontalo-utara/. [Accessed October 2, 2020]

[6] T. Saaty. "The Analytic Hierarchy and Analytic Network Processes for the Measurement of Intangible Criteria and for Decision-Making". 2016.

[7] I. Muzakkir. "Penerapan Metode Topsis Untuk Sistem Pendukung Keputusan Penentuan Keluarga Miskin Pada Desa Panca Karsa II”. ILKOM Jurnal Ilmiah, 9(3, )pp. 274-281. 2017

[8] M.R.A. Kaluku and N. Pakaya. "Penerapan Perbandingan Metode AHP-TOPSIS dan ANP-TOPSIS Mengukur Kinerja Sumber Daya Manusia di Gorontalo". Ilkom Jurnal Ilmiah, 9(2), pp. 124-131. 2017

[9] M.R.A. Kaluku and N. Pakaya. "Sistem Pengukuran Kinerja Sumber Daya Manusia Mengunakan Metode ANP-TOPSIS”. Seminar Nasional Aplikasi Teknologi Informasi. pp. D22-D27. 2017.

[10] S. Sarwindah and M. Marini. "Sistem Penilaian Kinerja Karyawan PT. Cahaya Iqra Mandiri menggunakan Metode Analytical Hierarchy Process". ILKOM Jurnal Ilmiah, 11(2), pp. 110-117. 2019

[11]M.A. Mude. "Perbandingan Metode SAW dan TOPSIS pada kasus UMKM". ILKOM Jurnal Ilmiah, 8(2), pp. 76-81. 2016

[12] G. Wibisono, A. Amrulloh and E. Ujianto. "Penerapan Metode Topsis Dalam Penentuan Dosen Terbaik”. ILKOM Jurnal Ilmiah, 11(2), pp. 102-109. 2019

[13]Z. Wang, H. Hao, F. Gao, Q. Zhang, J. Zhang and Y. Zhou. "Multi-Attribute Decision Making on Reverse Logistics Based on DEA-TOPSIS: A Study of the Shanghai End-of-Life Vehicles Industry". Journal of Cleaner Production. Pp. 730-737. 2019.

[14]X. Zhou and M. Lu. "Risk Evaluation of Dynamic Alliance Based on Fuzzy Analytic Network Process and Fuzzy TOPSIS". Journal of Service Science and Management, pp. 230-240. 2012

[15] E. Marbun and S. Hansun. "Sistem Pendukung Keputusan Pemilihan Program Studi dengan Metode Saw Dan Ahp". ILKOM Jurnal Ilmiah, 11(3), pp. 175-183. 2019

[16]H. Annur. "Aplikasi Sistem Pendukung Keputusan Penempatan Bidan di Desa Menggunakan Metode Analitycal Hierarchy Process (AHP)”. ILKOM Jurnal Ilmiah, 10(1), pp. 44-51. 2018

[17] A. Calabrese, R. Costa and T. Menichini. "Using fuzzy AHP to manage intellectual capital assets : an application to the ICT service industry”. Expert Systems with Applications. pp. 3747-3755. 2013. 